\title{
The influence of comorbid factors in surviving of patients with severe form of seasonal influenza
}

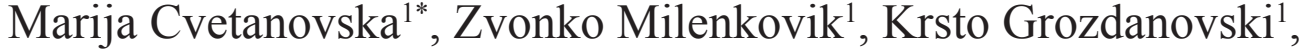 \\ Valerija Kirova Uroshevik ${ }^{1}$, Vlatko Cvetanovski² \\ ${ }^{1}$ Clinic of Infectious Diseases and Febrile Conditions, Clinical Center, Str. Majka Tereza 47, 1000 Skopje, R. Macedonia \\ ${ }^{2}$ General Hospital Remedika, $16^{\text {th }}$ Macedonian brigade, 1000, Skopje, R. Macedonia
}

Received: February 2016; Accepted: May 2016

\begin{abstract}
Elderly patients and patients with different comorbid conditions are at a higher risk of developing severe clinical course and lethal influenza outcome. The aim of this study was to define comorbid conditions in patients with a severe form of seasonal influenza, and to define their influence on lethal outcome. The study was a prospective, group comparison and was conducted at the University Clinic for Infectious Diseases in Skopje, Macedonia, during the period of January 01, 2012 to January 01, 2015. The study included 87 adult patients with a severe form of seasonal influenza, who were further categorized in to a group of either survived patients ( $\mathrm{n}=75$ ) and a group of deceased patients $(n=12)$. Demographic parameters of the patients, as well as any comorbid medical conditions, such as cardiovascular disease, chronic lung disease, neurological diseases, weakened immune system, endocrine disorders, kidney disorders, liver disorders, pregnancy, overweight were noted upon admission in the hospital. The variables of the univariate analysis that showed a significant difference in terms of the outcome were used for creating multivariate logistic and regression analysis to identify independent predictors for lethal outcome in severe cases of influenza. Multivariate analysis identified cardiovascular comorbid diseases $(p=0.014)$, as an independent predictor of the outcome in patients with severe form of seasonal influenza. Influenza patients with cardiovascular diseases had 2.024 times greater risk of death from influenza in comparison to patients having influenza without a history of such a disease (OR=2.024 95\% CI 1.842-17.337).
\end{abstract}

Keywords: influenza, cardiovascular diseases, comorbid conditions, predictors, lethal outcome

\section{Introduction}

Influenza is a serious disease with significant morbidity and mortality which clinical presentation ranges from relatively mild and self-limiting respiratory infections to severe clinical manifestations (Thompson et al., 2009). During seasonal epidemics from 3 to 5 million severe cases and about 250.000-500.000 lethal cases are registered worldwide (Puig-Barberà et al., 2015; World Health Organization, 2014). Until now there has been no laboratory test that can serve as a potential marker for identification of patients with a high risk of developing severe clinical forms

\footnotetext{
*mcvetanovska2001@yahoo.com
}

of influenza and lethal outcome (Blyth et al., 2009; Zimmerman et al., 2014). It is known that elderly patients and patients with different comorbid conditions such as diabetes mellitus, chronic cardiovascular and pulmonary diseases, immunosuppressive conditions, overweight patients, pregnant women and other conditions are at a higher risk of developing severe clinical course of the disease and lethal outcome (Kalyani et al., 2011). Although the influenza virus is primarily a respiratory pathogen, the severe clinical forms of the disease are manifested as systemic infections with multisystem organ affection, and even 10-30\% of the diseased need intensive treatment (Lee et al., 2010; Mata-Marín et al., 2015; Oh et al., 2009). Pneumonia is 
the most important reason for hospitalization, development of severe clinical course of the disease and lethal outcome (Woo., 2011). In most studies delayed antiviral treatment, severe hypoxemia and multisystem organ failure are most commonly referred as leading risk factors for lethal outcome (Damak et al., 2011; Webb et al., 2009). The largest number of studies has evaluated isolated risk factors leading to lethal outcome and only a few of them have been focused on the complete palette of predictors for development of a severe form of the disease and lethal outcome (Kumar et al., 2009; Li et al., 2009; Liu et al., 2009; Yokota, 2011). From the clinical practice point of view, the recognition of the risk factors and predictors for lethal outcome of influenza is of particular importance in bringing timely and exact decision for hospitalization, treatment or undertaking special measures for intensive monitoring of these patients.

Severe influenza is defined by signs of respiratory weakness (dyspnea, tachypnea, hypoxia, cyanosis) that is partial pressure of arterial oxygen $(\mathrm{PaO} 2<70 \mathrm{mmHg} ;<9.0$ $\mathrm{kPa}$ ) and/or need of mechanical ventilation or signs of acute respiratory distress syndrome $(\mathrm{PaO} 2 / \mathrm{FiO} 2 \leq 200)$, intensive care, severe complications, exacerbation of the existing chronic disease (Centers for Disease Control and Prevention, 2009-2010; World Health Organization, 2009).

The aim of this study was to define comorbid conditions in patients with a severe form of seasonal influenza, as well as to define their influence on lethal outcome.

\section{Material and methods}

The study was prospective, clinical, group comparison and it was conducted at the Clinic for Infectious Diseases and Febrile Conditions in a three-year-period (01 Jan. 2012-01 Jan. 2015).

A total of 87 patients with severe forms of clinically and laboratory confirmed influenza were analyzed. The patients were over 16 years old, divided into two groups. Group 1 included 75 patients who survived and group 2 comprised 12 patients who had lethal outcome. Patients were excluded if they died in the first 24 hours of their inclusion in the study. On admission of patients, the following parameters were noted: demographic characteristics, comorbidities (cardiovascular disease, chronic lung disease, neurological diseases, hematological and malignant disease, immunosuppressive therapy and immunosuppressive conditions, HIV infections, asplenia, insulin dependent diabetes, chronic renal failure, hepatic cirrhosis, obesity-body mass index $\geq 40$, pregnancy).

The study was designed in accordance with the ethics principles of the Declaration of Helsinki for patients and their rights, and was approved by the Ethics Committee of the Medical Faculty of Ss Cyril and Methodius University in Skopje.

Nasopharyngeal smear was used for detection of influenza virus. In the Laboratory of virology and molecular di- agnosis at the Institute for Public Health from the previously isolated RNA (ribonucleic acid) real time RT-PCR (reverse transcriptase/ion-polymerase chain reaction in real time) was performed.

The data were statistically analyzed with the SPSS for Windows 13.0 program, using relevant statistical methodologies. Distribution of frequencies (absolute and relative incidence) was used for qualitative parameters. Descriptive methods such as mean, median and mode were used for mean and typical values of data as well as measures of declination, standard deviation and standard error. For testing the significance of the difference between certain analyzed factors parametric tests (t-test for independent samples, Analysis of Variance) were used and non-parametric tests for independent samples (Mann-Whitney U test, Chi -square test, Fisher-exact test).

Regarding determination of prognostic factors of death in patients with influenza the method of multivariate analysis was used (Logistic Binary Regression), by which the relation of probability of exposure (OR) was determined as an approximate value of the real risk (RR). Statistical precision (OR) was obtained by calculation of the confidence intervals (CI) about the estimated values.

The value of $\mathrm{p}<0.05$ was considered to be statistically significant, and the value of $\mathrm{p}<0.01$ highly significant.

\section{Results}

From a total of 87 patients $13.79 \%$ died. Our results showed that females died insignificantly more often than men $(16.13 \%$ vs. $12.5 \%)(\mathrm{p}=0.64)$. The age had significant influence on the disease outcome $(p=0.019)$. The mean age of the deceased patients was $65.58 \pm 17.5$ years, opposite to the mean age of the survived patients which was $53.04 \pm 16.8$ years. The place of living of the patients had no significant influence on the outcome $(p=0.44)$, that is, patients from rural environment died insignificantly more often than patients from urban environment $(22.22 \% v s$. $12.82 \%$ ). Patients with positive epidemiological survey for influenza contacts died insignificant more often than patients with negative epidemiological survey of influenza contacts $(p=0.52)$. In the group of patients with positive epidemiological survey of influenza contacts $16.36 \%$ died vs. $9.38 \%$ in the group of patients with negative epidemiological survey of influenza contacts. The patient who was vaccinated against influenza overcame the disease whereas $13.95 \%$ of the patients who were not vaccinated died $(\mathrm{p}=1.0)$ (Table 1).

The results showed that mortality in the group of patients with severe influenza without comorbidities was $9.09 \%$ against the group of patients with comorbidities where mortality was higher $15.38 \%$. The difference in distribution between these two groups was statistically insignificant $(p=0.72)$. The analysis of the different chronic conditions showed that those disease have significant influence on the outcome in patients with influenza $(\mathrm{p}=0.011)$. Mor- 
Table 1. General characteristics of patients regarding outcome

\begin{tabular}{|c|c|c|c|c|}
\hline \multicolumn{5}{|c|}{ Severe influenza } \\
\hline Variable & $\begin{array}{l}\text { Total } \\
\mathrm{n}=87\end{array}$ & $\begin{array}{l}\text { Survived } \\
\qquad \mathrm{n}=75\end{array}$ & $\begin{array}{l}\text { Deceased } \\
\qquad \mathrm{n}=12\end{array}$ & $\mathrm{p}$ value \\
\hline \multicolumn{5}{|c|}{$\operatorname{Sex}[n(\%)]$} \\
\hline female & $31(35.63)$ & $26(83.87)$ & $5(16.13)$ & \multirow{2}{*}{${ }^{\mathrm{a}} 0.64$} \\
\hline male & $56(64.37)$ & $49(87.5)$ & $7(12.5)$ & \\
\hline \multicolumn{5}{|c|}{ Age groups $[\mathrm{n}(\%)]$} \\
\hline $16-49$ & $31(35.63)$ & $29(93.55)$ & $2(6.45)$ & \multirow[b]{3}{*}{${ }^{\mathrm{c}} 0.072$} \\
\hline $50-65$ & $34(39.08)$ & $30(88.24)$ & $4(11.76)$ & \\
\hline over 66 & $22(25.29)$ & $16(72.73)$ & $6(27.27)$ & \\
\hline \multicolumn{5}{|c|}{ Age $($ mean \pm SD $)$} \\
\hline & $54.77 \pm 17.3$ & $53.04 \pm 16.8$ & $65.58 \pm 17.5$ & b $0.019 *$ \\
\hline \multicolumn{5}{|c|}{ Place of living [n (\%)] } \\
\hline urban & $78(89.65)$ & $68(87.18)$ & $10(12.82)$ & \multirow{2}{*}{${ }^{\mathrm{a}} 0.438$} \\
\hline rural & $9(10.34)$ & $7(77.78)$ & $2(22.22)$ & \\
\hline \multicolumn{5}{|c|}{ Epidemiological survey [n (\%)] } \\
\hline positive & $55(63.22)$ & $46(83.64)$ & $9(16.36)$ & \multirow{2}{*}{${ }^{\mathrm{c}} 0.52$} \\
\hline negative & $32(36.78)$ & $29(90.63)$ & $3(9.38)$ & \\
\hline \multicolumn{5}{|c|}{ Vaccine $[\mathrm{n}(\%)]$} \\
\hline yes & $1(1.5)$ & $1(100)$ & 0 & \multirow{2}{*}{${ }^{\mathrm{c}} 1.0$} \\
\hline no & $86(98.85)$ & $74(86.05)$ & $12(13.95)$ & \\
\hline
\end{tabular}

${ }^{\mathrm{a}} \mathrm{p}$ (Chi-square test), ${ }^{\mathrm{b}} \mathrm{p}$ (Student's t-test), ${ }^{\mathrm{c}}\left(\right.$ Fisher exact test), ${ }^{*} \mathrm{p}<0.05$

tality in the group with a negative history of cardiovascular disease was $4.55 \%$ vs. $23.26 \%$ in the group of patients with cardiovascular disease. This difference is statistically significant. All other analyzed comorbidities were insignificantly associated with the outcome in patients with influenza. A small number of patients who had weakened immune system, liver disorders, obesity and pregnancy survived although they presented with a severe form of influenza (Table 2, Fig. 1).

Patients with influenza who died had insignificantly more comorbidities $(p=0.085)$ (Table 3$)$. cardiovascular disease (cd)

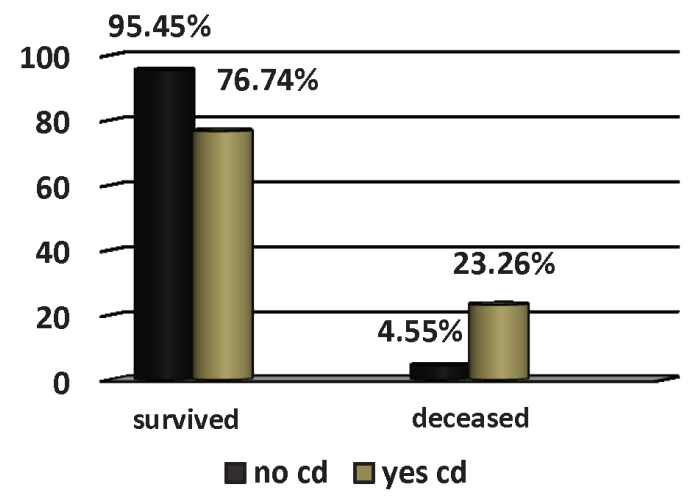

Fig. 1. Survived /deceased cardiovascular diseases. 
Table 2. Comorbidities and types of comorbidities in patients regarding outcome

\begin{tabular}{|c|c|c|c|c|}
\hline \multirow{3}{*}{ Variable } & \multicolumn{2}{|c|}{ Severe influenza } & \multirow{3}{*}{$\begin{array}{l}\text { Decease } \\
n=12\end{array}$} & \multirow{3}{*}{$\mathrm{p}$ value } \\
\hline & Total & Survived & & \\
\hline & $\mathrm{n}=87$ & $\mathrm{n}=75$ & & \\
\hline \multicolumn{5}{|l|}{ Comorbidities [n (\%)] } \\
\hline no & $22(25.29)$ & $20(90.91)$ & $2(9.09)$ & \multirow{2}{*}{${ }^{\mathrm{c}} 0.72$} \\
\hline yes & $65(74.71)$ & $55(84.62)$ & $10(15.38)$ & \\
\hline \multicolumn{5}{|c|}{ Cardiovascular disease $[\mathrm{n}(\%)]$} \\
\hline no & $44(50.57)$ & $42(95.45)$ & $2(4.55)$ & \multirow{2}{*}{ a 0.011} \\
\hline yes & $43(49.42)$ & $33(76.74)$ & $10(23.26)$ & \\
\hline \multicolumn{5}{|c|}{ Chronic lung diseases $[\mathrm{n}(\%)]$} \\
\hline no & $74(85.06)$ & $63(85.14)$ & $11(14.86)$ & \multirow{2}{*}{${ }^{\mathrm{c}} 0.68$} \\
\hline yes & $13(14.94)$ & $12(92.31)$ & $1(7.69)$ & \\
\hline \multicolumn{5}{|c|}{ Neurological diseases [n (\%)] } \\
\hline no & $77(88.51)$ & $67(87.01)$ & $10(12.99)$ & \multirow{2}{*}{${ }^{\mathrm{c}} 0.62$} \\
\hline yes & $10(11.49)$ & $8(80)$ & $2(20)$ & \\
\hline \multicolumn{5}{|l|}{ Kidney disease $[\mathrm{n}(\%)]$} \\
\hline no & $82(94.25)$ & $72(87.8)$ & $10(12.2)$ & \multirow{2}{*}{${ }^{\mathrm{c}} 0.14$} \\
\hline yes & $5(5.75)$ & $3(60)$ & $2(40)$ & \\
\hline \multicolumn{5}{|c|}{ Endocrine disease $[\mathrm{n}(\%)]$} \\
\hline no & $70(80.46)$ & $60(85.71)$ & $10(14.29)$ & \multirow{2}{*}{${ }^{\mathrm{c}} 1.0$} \\
\hline yes & $17(19.54)$ & $15(88.24)$ & $2(11.76)$ & \\
\hline \multicolumn{5}{|c|}{ Hematology disease $[\mathrm{n}(\%)]$} \\
\hline no & $81(93.1)$ & $70(86.42)$ & $11(13.58)$ & \multirow{2}{*}{${ }^{\mathrm{c}} 1.0$} \\
\hline yes & $6(6.89)$ & $5(83.33)$ & $1(16.67)$ & \\
\hline \multicolumn{5}{|c|}{ Immunology disease and AIDS $[\mathrm{n}(\%)]$} \\
\hline no & $86(98.85)$ & $74(86.05)$ & $12(13.95)$ & \multirow{2}{*}{${ }^{\mathrm{c}} 1.0$} \\
\hline yes & $1(1.15)$ & $1(100)$ & 0 & \\
\hline \multicolumn{5}{|c|}{ Malignant diseases [n (\%)] } \\
\hline no & $87(100)$ & $75(86.21)$ & $12(13.79)$ & \\
\hline yes & 0 & 0 & 0 & \\
\hline \multicolumn{5}{|l|}{ Liver disease $[\mathrm{n}(\%)]$} \\
\hline no & $86(98.85)$ & $74(86.05)$ & $12(13.95)$ & \multirow{2}{*}{${ }^{\mathrm{c}} 1.0$} \\
\hline yes & $1(1.15)$ & $1(100)$ & 0 & \\
\hline \multicolumn{5}{|l|}{ Pregnancy [n (\%)] } \\
\hline no & $85(97.7)$ & $73(85.88)$ & $12(14.12)$ & \multirow{2}{*}{${ }^{\mathrm{c}} 1.0$} \\
\hline yes & $2(2.3)$ & $2(100)$ & 0 & \\
\hline \multicolumn{5}{|l|}{ Obesity $[\mathrm{n}(\%)]$} \\
\hline no & $85(97.7)$ & $73(85.88)$ & $12(14.12)$ & \multirow{2}{*}{ c1.0 } \\
\hline yes & $2(2.3)$ & $2(100)$ & 0 & \\
\hline
\end{tabular}


Table 3. Number of comorbidities regarding outcome

$$
\text { Severe influenza }
$$

\begin{tabular}{ccccc}
$\begin{array}{c}\text { Number of } \\
\text { comorbidi- } \\
\text { ties }\end{array}$ & $\begin{array}{c}\text { Total } \\
\mathrm{n}(\%)\end{array}$ & $\begin{array}{c}\text { Survived } \\
\mathrm{n}(\%)\end{array}$ & $\begin{array}{c}\text { Deceased } \\
\mathrm{n}(\%)\end{array}$ & $\begin{array}{c}{ }^{\mathrm{d}} \mathrm{p} \\
\text { value }\end{array}$ \\
\hline 1 & $38(48.1)$ & $36(52.17)$ & $2(20)$ & \\
2 & $27(34.18)$ & $22(31.88)$ & $5(50)$ & 0.085 \\
$>2$ & $14(17.72)$ & $11(15.49)$ & $3(30)$ & \\
\multicolumn{4}{c}{ Mann-Whitney U test }
\end{tabular}

Table 4 presents the results from the univariate logistic regression analysis in determining the analyzed demographic and comorbid variables that have confirmed to be predictors of the lethal outcome.

Table 4. Univariate Logistic Regression analysis for prediction of lethal outcome in patients with influenza

\begin{tabular}{lcl}
\hline \multicolumn{1}{c}{ Variable } & $\begin{array}{c}\text { Crude OR } \\
95 \% \text { CI for OR }\end{array}$ & p value \\
\hline \multicolumn{2}{c}{ Demographic variables } & \\
\hline Age & $1.05(1.006-1.095)$ & $0.025^{*}$ \\
Men vs. women & $0.743(0.214-2.573)$ & 0.639 \\
Village vs. town & $1.943(0.353-10.698)$ & 0.445 \\
$\begin{array}{l}\text { Comorbidity } \\
\text { Number of co }\end{array}$ & $1.818(0.366-9.025)$ & 0.465 \\
$\begin{array}{l}\text { morbidities } \\
\text { Cardiovascular } \\
\text { disease }\end{array}$ & $6.167(0.903-11.102)$ & 0.072 \\
\hline
\end{tabular}

Variables in the univariate logistic regression analysis, which were significantly associated with lethal outcome, were included in the multivariate logistic regression analysis in order to determine independent predictors for lethal outcome in patients with influenza. The results of these analyses showed that cardiovascular diseases were the only significant independent predictors for lethal outcome $(\mathrm{p}=0.014)$.

Patients with influenza and cardiovascular diseases had 2.024 times higher risk of death by influenza when compared to patients with influenza without history of cardiovascular comorbidity (OR=2.024 95\% CI 1.84217.337) (Table 5).

Table 5. Multivariate logistic regression analysis for prediction of lethal outcome

\begin{tabular}{ccc}
\hline \hline Variable & $\begin{array}{c}\text { Adjusted OR } \\
95 \% \text { CI for OR }\end{array}$ & p value \\
\hline Cardiovascular & $2.024(1.842-17.337)$ & $0.014^{*}$ \\
\hline
\end{tabular}

ROC analysis has demonstrated that cardiovascular disease is a good prognostic factor of the lethal outcome.
The area under the ROC curve, that is, AUC was 0.755, with $95 \%$ confidence interval from $0.587-0.923$ suggesting that the probability of that predictor for death in influenza patients was $75.5 \%$. The global precision of this predictor to foresee the lethal outcome was $80 \%$, sensitivity was $82 \%$ and specificity $70 \%$.

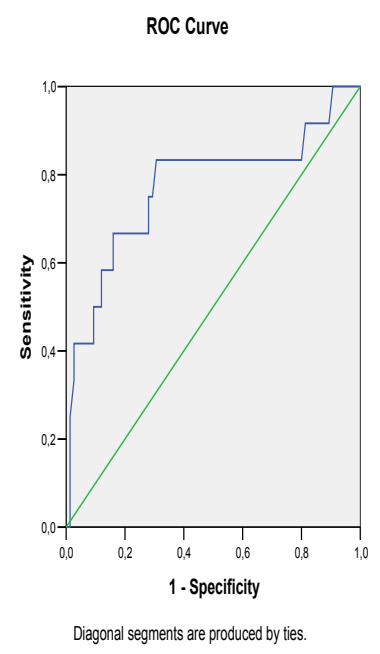

Fig. 2. ROC curve for the influence of cardiovascular diseases in prediction of lethal outcome from influenza

\section{Discussion}

Gender, age and place of living were evaluated as demographic variables in our study. The results showed that from a total of 12 lethal outcomes $5(16.1 \%)$ were women, and 7 (12.5\%) were men. Regarding gender our study showed different results compared to a large number of studies, where male gender was identified as a risk factor for a severe form of influenza (Cao et al., 2009; Kumar et al., 2009). Our study is similar to that conducted in Canada where from a total number of 29 lethal outcomes, $27.6 \%$ were men, whereas $72.4 \%$ were women (Mata-Marín et al., 2015). There was no significant difference in the mortality between our male and female patients. The age had significant influence on the disease outcome in our study. The mean age of patients that died was $65.58(\mathrm{p}=0.019)$. The mortality was the highest in patients at the age over $65(27.2 \%)$. These results coincide with almost all studies in the world that identify the old age as an important risk factor for mortality in patients with influenza (Chen et al., 2009; Perez-Padilla et al., 2009; Rodríguez et al., 2010). The place of living of the patients was not significant in relation to the outcome. Patients from both the rural and environments died, $22.2 \%$ vs. $12.8 \%$.

Only one of our patients was vaccinated and he survived. Eighty-six (98.8\%) patients were vaccinated, with 
mortality rate of $13.9 \%$. Due to the small number of patients this difference between the two groups was insignificant. These results shoud be taken with precaution since many studies show that vaccination significantly reduces mortality rate of influenza (De Florentiis et al., 2010; Moa et al., 2016; Sridhar et al., 2015).

The results obtained in our study have shown that the mortality rate in the group of patients with severe influenza without comorbidities was $9.09 \%$ whereas in the group of patients with associated comorbidities the mortality rate was higher $(15.38 \%)(\mathrm{p}=0.72)$. The analysis of identified associated chronic conditions has shown that cardiovascular diseases had significant influence on the outcome $(\mathrm{p}=0.011)$. Two $(4.55 \%)$ of influenza patients with a negative history of cardiovascular comorbidity died, whereas a significantly higher percentage of patients with associated cardiovascular diseases died (23.26\%). All other chronic diseases were insignificantly associated with the lethal outcome in influenza patients. A small number of patients who had immunological diseases (1), liver diseases (1), and obesity (2) in the group of severe form of influenza survived. Two pregnant women also survived. A large number of studies show that patients with one or more comorbidities needed to be hospitalized in intensive care units, and some of them were at a risk to die (Campbell et al., 2010; Kalyani1 et al., 2011). Multivariate logistic regression analysis detected only cardiovascular diseases as independent risk factors for severe seasonal influenza and lethal outcome in our study. This is in correlation with a large number of studies, where besides cardiovascular diseases, many other comorbidities have been presented, such as pulmonology and immunological diseases. A large number of studies has detected pregnancy as a risk factor for complications and lethal outcome in a severe form of influenza, and emphasize that the highest risk is in last three months. (Jamieson et al., 2009; Louie et al., 2010). However, one study did not detect any lethal outcome in a total of 211 pregnant women (Lim et al., 2010). In our study pregnancy was not significantly associated with any complication, miscarriage, premature birth, fetal distress, severe clinical course and lethal outcome. This might be due to a small number of pregnant women included in our study, and one of them had early antiviral treatment.

Univariate logistic regression analysis for predicting the letal outcome in patients of sesonal influenza emphasized the age from the demongraphic variables $(p=0.025)$ and cardiovascular diseases from comorbidities $(\mathrm{p}=0.022)$ as predictors for lethal outcome. The variables of the univariate analysis that showed a significant difference in terms of a lethal outcome were used to create multivariate logistic and regression analysis in order to determine the independent predictors for lethal outcome in patient with influenza. Our analysis determined cardiovascular diseases as an independent predictors for lethal outcome of severe seasonal influenza $(p=0.014)$. Patients with influenza and cardiovascular diseases had 2.024 times higher risk of death of influenza compared to influenza patients without history of cardiovascular comorbidities ( $\mathrm{OR}=2.02495 \%$ CI 1.842-17.337).

\section{Conclusion}

Cardiovascular diseases were the most frequent comorbidity in our studi as an independent variable for the unfavorable outcome in patients with severe influenza. Early detection of patients with a high risk of a severe form of influenza can help in implementing adequate medical measures that will contribute to reducing the mortality rate from these diseases.

\section{References}

Blyth, C.C., Iredell, J.R., Dwyer. D.E., 2009. Rapid-test sensitivity for novel swine-origin influenza A (H1N1) virus in humans. N. Engl. J. Med. 361(25), 2493.

Cao, B., Li, X.W., Mao, Y., Wang, J., Lu, H.Z., Chen, Y.S., Liang, Z.A., Liang, L., Zhang, S.J., Zhang, B., Gu, L., Lu, L.H., Wang, D.Y., Wang, C., 2009. Clinical features of the initial cases of 2009 pandemic influenza A (H1N1) virus infection in China. N. Engl. J. Med. 361, 2507-2517.

Campbell, A., Rodin, R., Kropp, R., Mao, Y., Hong, Z., Vachon, J., Spika, J., Pelletier, L., 2010. Risk of severe outcomes among patients admitted to hospital with pandemic (H1N1) influenza. CMAJ 182, 349-355.

Chen, K.F., Gaydos, C., Rothman, R.E., 2009. Update on emerging infections: news from the Centers for Disease Control and Prevention. Hospitalized patients with novel influenza A (H1N1) virus infection--California, April-May, 2009. Ann. Emerg. Med. 54(5), 732-736.

Damak, H., Chtara, K., Bahloul, M., Kalle,1H., Chaari, A., Ksibi, H., 2011. Clinical features, complications and mortality in critically ill patients with 2009 influenza A(H1N1) in Sfax,Tunisia. Influenza Other Respir. Viruses 5(4), 230-240.

De Florentiis, D., Parodi, V., Orsi, A, Rossi A, Altomonte, F., Canepa, P., Ceravolo, A., Valle, L., Zancolli, M., Piccotti, E., Renna, S., Macrina, G., Martini, M., Durando, P., Padrone, D., Moscatelli, P., Orengo, G., Icardi, G., Ansaldi, F., 2010. Impact of influenza during the post-pandemic season: epidemiological picture from syndromic and virological surveillance. J. Prev. Med. Hyg. 52, 134-136.

Jamieson, D.J., Honein, M.A., Rasmussen, S.A., Williams, J.L., Swerdlow, D.L., Biggerstaff, MS., Lindstrom, S., Louie, J.K., Christ, C.M., Bohm, S.R., Fonseca, V.P., Ritger, K.A., Kuhles, D.J., Eggers, P., Bruce, H., Davidson, H.A., Lutterloh, E., Harris, M.L., Burke, C., Cocoros, N., Finelli, L., MacFarlane, K.F,, Shu, B., Olsen, S.J., 2009. Novel Influenza A (H1N1) Pregnancy Working Group. H1N1 2009 influenza virus infection during pregnancy in the USA. Lancet 374, 451-458.

Kalyanil, D., Srikanth Bhatt, S., Chitralekha, T., Rajarao, M., Shankar, K., 2011. Comorbidities In H1N1 Positive Patients - Hospital Based Study, IOSR. Journal of Dental and Medical Sciences 15, 52-55.

Kumar, A., Zarychanski, R., Pinto, R., Cook, D., Marshall, J., Lacroix, J., Stelfox, T., Bagshaw, S., Choong, K., 
Lamontagne, F., Turgeon, A., Lapinsky, S., Ahern, S., Smith, O., Siddiqui, F., Jouvet, P., Khwaja, K., McIntyre, L., Menon, K., Hutchison, J., Hornstein, D., Joffe, A., Lauzier, F., Singh, J., Karachi, T., Wiebe, K., Olafson, K., Ramsey, C., Sharma, S., Dodek, P., Meade, M., Hall, R., Fowler, R., 2009. Critically ill patients with 2009 influenza A (H1N1) infection in Canada. JAMA 302, 1872-1879.

Lee, N., Choi, K.W., Chan, P.K., Hui, D.S., Lui, G.C., Wong, B.C., Wong, R.Y., Sin, W.Y., Hui, W.M., Ngai, K.L., Cockram, C.S., Lai, R.W., Sung, J.J., 2010. Outcomes of adults hospitalised with severe influenza. Thorax 65, 510515.

Li, G., Yilmaz, M., Kojicic, M., Fernández-Pérez, E., Wahab, R., Charles Huskins, W., Afessa, B., Truwit, J..D., Gajic, O., 2009. Outcome of critically ill patients with influenza virus infection. J. Clin. Virol. 46(3), 275-278.

Lim, M.L., Chong, C.Y., Tee, W.S., Lim, W.Y., Chee, J.J., 2010. Influenza A/H1N1 (2009) infection in pregnancy-an Asian perspective. BJOG 117, 551-556.

Liu, L., Zhang, R.F., Lu, H.Z., Lu, S.H., Huang, Q., Xiong, Y.Y., Xi, X.H., Zhang, Z.Y., 2011. Sixty-two severe and critical patients with 2009 influenza A (H1N1) in Shanghai, China. Chin. Med. J. (Engl). 24(11), 1662-1666.

Louie, J.K., Acosta, M., Jamieson, D.J., Honein, M.A., 2010. California Pandemic (H1N1) Working Group. Severe 2009 H1N1 influenza in pregnant and postpartum women in California. N. Engl. J. Med. 362, 27-35.

Mata-Marín, L.A., Mata-Marín, J.A., Vásquez-Mota, V.C., Arroyo-Anduiza, C.I., Gaytán-Martínez, J. E., ManjarrezTéllez, B., Ochoa-Carrera, L.A., Sandoval-Ramírez, J. L, 2015. Risk factors associated with mortality in patients infected with influenza $\mathrm{A} / \mathrm{H} 1 \mathrm{~N} 1$ in Mexico. BMC Res. Notes 8, 432.

Moa, A.M., Chughtai, A.A., Muscatello, D.J., Turner, R.M., MacIntyre, C.R., 2016. Immunogenicity and safety of inactivated quadrivalent influenza vaccine in adults: A systematic review and meta-analysis of randomised controlled trials. Vaccine 34(35), 4092-4102.

Oh, W.S., Lee, S.J., Lee, C.S., Hur, J.A., Hur, A.C., Park, Y.S., Heo, S.T., Bae, I.G., Park, S.W., Kim, E.S., Kim, H.B., Song, K.H., Lee, K.S., Lee, S.R., Yeom, J.S., Lee, S.J., Kim, B.N., Kwak, Y.G., Lee, J.H., Kim, Y.K., Kim, H.Y., Kim, N.J., Oh, M.D., 2009. A prediction rule to identify severe cases among adult patients hospitalized with pandemicinfluenza A (H1N1). J. Korean Med. Sci. 26(4), 499-506.

Perez-Padilla, R., De la Rosa-Zamboni, D., Ponce de Leon, S., Hernandez, M., Quiñones-Falconi, F., Bautista, E., RamirezVenegas, A., Rojas-Serrano. J., Ormsby, C.E., Corrales, A., Higuera, A., Mondragon, E., Cordova-Villalobos, J.A., 2009. INER Working Group on Influenza. Pneumonia and Respiratory Failure from Swine-Origin Influenza A (H1N1) in Mexico. N. Engl. J. Med. 361(7), 680-689.

Puig-Barberà, J., Tormos, A., Trushakova, S., Sominina, A., Pisareva, M., Ciblak, M.A., Badur, S., Yu, H., Cowling, B.J., Burtseva, E., 2015. The Global Influenza Hospital
Surveillance Network (GIHSN): A new platform to describe the epidemiology of severe influenza. Influenza Other Respir. Viruses 9(6), 277-286.

Rodríguez, A., Socías, L., Guerrero, J.E., Figueira, J.C., González, N., Maraví-Poma, E., Lorente, L., Martín, M., Albaya-Moreno, A., Algora-Weber, A., Vallés, J., León-Gil, C., Lisboa, T., Balasini, C., Villabón, M., Pérez-Padilla, R., Barahona, D., Rello, J., 2010. Grupo Español de Trabajo de Gripe A Grave/Sociedad Española de Medicina Intensiva, Crítica y Unidades Coronarias. Pandemic Influenza A in the ICU: Experience in Spain and Latin America. Med. Intensiva 34(2), 87-94.

Sridhar, S., Brokstad, K.A., Cox, R.J., 2015. Influenza vaccination strategies: comparing inactivated and live attenuated influenza vaccines. Vaccines 3, 373-389.

Thompson, W.W., Moore, M.R., Weintraub, E., Cheng. P-Y., Jin, X., Bridges, C.B., Bresee, J.S., Shay, D.K., 2009. Estimating Influenza-Associated Deaths in the United States. Am. J. Public Health 99(2), 225-230.

United States Centers for Disease Control and Prevention, 2009. Updated interim recommendations for the use of antiviral medications in the treatment and prevention of influenza for the 2009-2010 season. Available at: http://www.cdc.gov/ h1n1flu/recommendations.htm.

Woo, H.C., Yun, S.K., Doo, S.J., Ji, E.K., Kun, I.K., Hee, Y.S., Ki, U.K., Hye, K.P., Min, K.L., Soon, K.P., Yeon, J., 2011. Outcome of pandemic H1N1 pneumonia: clinical and radiological findings for severity assessment. Korean J. Intern. Med. 26, 160-167.

World Health Organization, 2009. Clinical management of human infection with pandemic (H1N1) 2009: revised guidance. Available at: www.who.int/csr/.../swineflu/ clinical_management/en/. (Accessed 14 August 2014).

World Health Organization, 2014. Influenza (seasonal). Available at: http://www.who.int/mediacentre/factsheets/fs211/en/. (Accessed 14 August 2014).

Webb, S.A., Pettilä, V., Seppelt, I., Bellomo, R., Bailey, M., Cooper, D.J., Cretikos, M., Davies, A.R., Finfer, S., Harrigan, P.W., Hart, G.K., Howe, B., Iredell, J.R., McArthur, C., Mitchell, I., Morrison, S., Nichol, A.D., Paterson, D.L, Peake, S., Richards, B., Stephens, D., Turner, A., Yung, M., 2009. Critical care services and 2009 H1N1 influenza in Australia and New Zealand. N. Engl. J. Med. 361, 19251934.

Yokota, R.T., Skalinski, L.M., Igansi, C.N., De Souza, L.R., Iser, B.P., Reis, P.O., Barros, E.N., Macário, E.M., Bercini, M.A., Ranieri, T.M., Araújo, W.N., 2011. Risk factors for death from pandemic (H1N1) 2009, southern Brazil. Emerg. Infect. Dis. 17(8), 1467-1471.

Zimmerman, O., Rogowski, O., Aviram, G., Mizrahi, M., Zeltser, D., Justo, D., Dahan, E., Arad, R., Touvia, O., Tau, L., Tarabeia Berliner, S., Paran, Y., 2010. C-reactive protein serum levels as an early predictor of outcome in patients with pandemic $\mathrm{H} 1 \mathrm{~N} 1$ influenza A virus infection. $B M C$ Infectious Diseases 10, 288. 


\title{
Влијание на коморбидните фактори на преживувањето кај пациентите со тешка форма на сезонска инфлуенца
}

\author{
Марија Цветановска ${ }^{1 *}$, Звонко Миленковиќ ${ }^{1}$, Крсто Гроздановски ${ }^{1}$, \\ Валерија Кирова-Урошевиќ ${ }^{1}$, Влатко Цветановски ${ }^{2}$

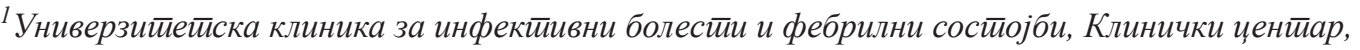 \\ Мајка Тереза 47, 1000 Скойје, Р. Макеяонија

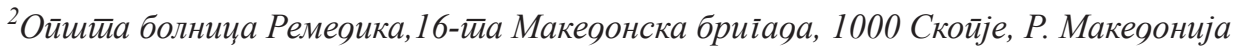

Клучни зборови: инфлуенца, кардиоваскуларни заболувања, коморбидни состојби, предиктори, летален исход

Инфлуенца е сериозно заболување со значителен морбидитет и морталитет. Возрасните пациенти и пациентите со различни коморбидни состојби се со зголемен ризик за развој на тежок клинички тек на болеста и смрт. Целта на овој труд е да се дефинираат коморбидните состојби кај пациентите со тешка форма на сезонска инфлуенца, како и да се утврди нивното влијание врз преживувањето. Истражувањето беше проспективно, групно споредбено и беше изведено на Универзитетската клиника за инфективни болести во Скопје, Р. Македонија во период од 1 јануари 2012 до 1 јануари 2015 година. Во студијата беа вклучени возрасни пациенти со тешка форма на сезонска инфлуенца кои понатаму беа поделени на група преживеани и група починати пациенти. При вклучување во студијата беа забележувани демографските податоци и придружните коморбидни состојби. Параметрите од униваријантната анализа кои покажаа значајна разлика во однос на исходот беа употребени за мултиваријантна логистичка регресивна анализа за исходот како зависни фактори. Со лигистичката регресија беа добиени независни предиктори за смртен исход од тешка форма на сезонска инфлуенца. Во студијата беа вклучени 87 пациенти со тешка форма на клинички и лабораториски потврдена сезонска инфлуенца. Болните беа поделени во две групи, преживеани $(\mathrm{n}=75)$ и починати $(\mathrm{n}=12)$. Смртноста кај оваа група пациенти изнесуваше 13,79 . Мултиваријантната анализа при приемот ги издвои кардиоваскуларните коморбидни болести $(\mathrm{p}=0,014)$ како независни показатели кои го предвидуваат исходот кај болните со тешка инфлуенца. Пациентите со инфлуенца и кардиоваскуларни заболувања имаат за 2,024 пати поголема шанса за смрт од инфлуенца во споредба со пациентите со инфлуенца без историја за кардиваскуларни коморбидитети $(\mathrm{OR}=2,024$ 95\% CI 1,842-17,337). Кардиоваскуларните заболувања како најчесто застапени коморбидни состојби во нашата студија се издвоија како независни предиктори кои на самиот прием предвидуваат неповолен исход кај болните со тешка инфлуенца. 